\title{
The physical, chemical and functional characterization of starches from Andean tubers: Oca (Oxalis tuberosa Molina), olluco (Ullucus tuberosus Caldas) and mashua (Tropaeolum tuberosum Ruiz \& Pavón)
}

\author{
Beatriz Valcárcel-Yamani', Gerby Giovanna Rondán-Sanabria², Flavio Finardi-Filho,"*
}

${ }^{1}$ Department of Biochemical-Pharmaceutical Technology, Faculty of Pharmaceutical Sciences, University of São Paulo, SP, Brazil, ${ }^{2}$ Department of Food and Experimental Nutrition, Faculty of Pharmaceutical Sciences, University of São Paulo, SP, Brazil

\begin{abstract}
The physical, chemical, and functional properties of starches isolated from the Andean tubers oca (Oxalis tuberosa M.), olluco (Ullucus tuberosus C.) and mashua (Tropaeolum tuberosum R. \& P.) were studied. The tubers were obtained from a local grocery. The morphology of the starch granules (size and shape) was studied with scanning electron microscopy (SEM), which revealed ellipsoid, oval, conical, pear-shaped and prismatic forms: ellipsoids and oval granules with lengths up to $54.30 \mu \mathrm{m}$ in oca; with lengths up to $32.09 \mu \mathrm{m}$ for olluco starch granules; and with predominantly truncated spherical or oval forms and smaller dimensions (up to $16.29 \mathrm{um}$ ) for mashua starch granules. Amylose contents were similar among the samples: $27.60 \%$ (oca), $26.49 \%$ (olluco) and $27.44 \%$ (mashua). Olluco starch had less swelling power, forming opaque, less firm gels. All three starch gels showed the same stability on refrigeration and presented high syneresis under freezing temperatures, with a variation of 40.28 to $74.42 \%$ for olluco starch. The starches cooked easily, with high peak viscosity. The low gelatinization temperatures and high stability during cooling make these starches suitable feedstock for use in formulations that require milder processing temperatures and dispense freezing storage.
\end{abstract}

Uniterms: Andean tubers/physiochemical properties. Andean tubers/functional properties. Tuber starches. Scanning electron microscopy/chemical analysis.

As propriedades físicas, químicas e funcionais de amidos isolados das tuberosas andinas, oca (Oxalis tuberosa M.), olluco (Ullucus tuberosus C.) e mashua (Tropaeolum tuberosum R. \& P.), obtidas no comércio local, foram estudadas. A morfologia dos grânulos de amido foi avaliada por microscopia eletrônica de varredura (SEM) revelando formas elipsoidais, ovais, cônicas, periformes e prismáticas: grânulos elipsoides e ovais com dimensões de até $54,30 \mu \mathrm{m}$ de comprimento para a oca, de até 32,09 $\mu \mathrm{m}$ para o amido de olluco, e com formas predominantemente esféricas ou ovais truncadas, de menores dimensões de até 16,29 $\mu \mathrm{m}$ para grânulos de amido de mashua. Os conteúdos de amilose foram similares entre as amostras: $27,60 \%$ (oca), 26,49\% (olluco) e 27,44\% (mashua). O amido de olluco teve menor poder de intumescimento, formando géis opacos e menos resistentes. Os géis dos três amidos mostraram a mesma estabilidade sob refrigeração e apresentaram alta sinérese após congelamento, com variação de 40,28 a 74,42\% para amido de olluco. Os amidos tiveram cocção rápida com alto pico de viscosidade. A baixa temperatura de gelatinização e alta estabilidade durante a refrigeração fazem destes amidos matérias-primas adequadas para formulações que requeiram temperaturas brandas de processamento e que dispensem conservação por congelamento.

Unitermos: Tuberosas andinas/propriedades funcionais. Tuberosas andinas/propriedades fisico-químicas. Amidos de tuberosas. Microscopia eletrônica de varredura/análise química.

\footnotetext{
"Correspondence: F. Finardi-Filho. Departamento de Alimentos e Nutrição Experimental, Faculdade de Ciências Farmacêuticas, Universidade de São Paulo. Av. Prof. Lineu Prestes, 580. Butantã - 05508-900 - São Paulo - SP, Brasil. E-mail: ffinardi@usp.br
} 


\section{INTRODUCTION}

The Andean region is known for its great diversity of roots and tubers, which are consumed by the rural population as staple foods because of their high amounts of carbohydrates, especially starch. These plants are distinguished by their variety of shapes, flavors and consumption habits and their importance in the regional diet. Examples of Andean roots and tubers are the oca (Oxalis tuberosa Molina), olluco (Ullucus tuberosus Caldas), mashua (Tropaeolum tuberosum Ruiz and Pavón), potato (Solanum tuberosum), Peruvian carrot (Arracacia xanthorrhiza) and maca (Lepidium meyenii W.).

According to the National Research Council (USA, 1989), oca has a nutritional value equal to or better than potato. On average, oca contains $84.1 \%$ water, $1.1 \%$ protein and $0.6 \%$ lipid. Fourteen percent of its content is attributed to carbohydrates, and sucrose is the main sugar. (Gross et al., 1989). Olluco contains up to $85 \%$ water, $1-2 \%$ protein and $14 \%$ carbohydrate (USA, 1989). According to Gross et al. (1989), the main sugars in olluco are glucose and fructose. Mashua contains $11 \%$ carbohydrate. On a dry basis the protein content varies between 6.9 and 15.9\% (USA, 1989). According to Barrera et al., (2004), mashua contains the highest amount of vitamin C (77.37 mg in $100 \mathrm{~g}$ of fresh matter) among all tubers. The provitamin A content, expressed as retinol equivalents (RE), identifies mashua as the most carotene-rich species of tuber, with an average level of 73.56 RE/100 g fresh matter (Barrera, et al., 2004).

The search for natural starch products has led to the study of new sources to replace chemically modified starches. For this reason, the number of studies of the physicochemical properties of nonconventional species has increased in recent years, prompting the interest of the food industry and other sectors, which in turn could increase small farmers' yields. Among the new sources being studied are biri (Canna edulis), ginger (Zingiber officinale), arrowroot (Maranta arundinacea), sweet potato (Ipomoea batatas) and yam (Dioscorea alata) (Peroni, Rocha, Franco, 2006), oca, olluco (HernandezLauzardo et al., 2004), maca and Peruvian carrot (RondánSanabria, Finardi-Filho, 2009).

The proportion of the two main constituents of starch, amylose and amylopectin, differs according to the botanical source, the variety of the species, and even the degree of maturation within the same plant (Tester, Karkalas, Qi, 2004). In addition to being the predominant reserve carbohydrate and providing the primary source of energy in the human diet, starch is also highly important in many industrial sectors as a raw material in food, drug and cosmetic manufacturing and, more recently, in the development of biomaterials. Starch can be used in its natural form or through additional processing, which results in products such as modified starches, glucose, maltose or fructose syrups, and maltodextrins. As a biomaterial, it is used to obtain extrusion biofilms for thermoformers with various applications (Godbillot et al., 2006; Rocha, Demiate, Franco, 2008).

Native starches have unique physicochemical and functional characteristics. These properties include the temperature of gelatinization, retrogradation, solubility, swelling power, syneresis and the rheological behavior of pastes and gels. These properties are influenced by the structural characteristics, shape and botanical source of the starch (Hermansson, Svegmark, 1996).

Although several studies have examined the different applications of starch, it is necessary nonetheless to evaluate new starch sources with specific characteristics to meet new applications and demands in the industrial sector (Torruco-Uco, Betancur-Ancona, 2007). This study aims to characterize the physicochemical and functional properties of three tubers originating in the Peruvian Andes: oca, olluco and mashua.

\section{MATERIAL AND METHODS}

\section{Material}

Samples of yellow oca, yellow olluco and yellow mashua were collected at a local market in Arequipa, Peru within five days after harvest. The tubers were washed with distilled water and dried at room temperature. After cleaning, one part was used for starch extraction and another part was stored in polyethylene bags and frozen at $-20{ }^{\circ} \mathrm{C}$ until use.

All reagents were purchased from Sigma Chemical Co., Aldrich Chemical Co., Invitrogen or GE Life Sciences.

\section{Starch extraction}

The starches from oca, olluco and mashua were extracted according to the methods described by Singh et al., (2006) and Torruco-Uco and Betancur-Ancona (2007), with some adjustments.

Healthy samples that were free of impurities were manually cut into small cubes (approximately $3 \mathrm{~mm}$ ) and ground in a blender with distilled water (1:2) for $3 \mathrm{~min}$. The homogenate was filtered through three layers of a thin membrane of cotton and the filtrate was collected in a beaker. The residue retained on the membrane was 
discarded and the filtrate containing the starch was resuspended in distilled water $(1: 4)$ and left to rest for $4 \mathrm{~h} / 4^{\circ} \mathrm{C}$ until the starch settled. Afterwards, the starch was separated from the supernatant and resuspended in water. This washing procedure was repeated approximately five times to obtain a white starch and a translucent supernatant. The starch was collected and dried at room temperature under forced air circulation for approximately $12 \mathrm{~h}$. The dry starch was weighed and stored at $-20^{\circ} \mathrm{C}$.

The extraction of olluco starch required the use of the antioxidant sodium sulfite at a concentration of $0.03 \%$, in accordance with established food legislation (Brasil, 2005) to avoid enzymatic oxidation, mainly by peroxidases and phenolases. This antioxidant was only employed during the first extraction phase, during tuber milling. The subsequent steps were performed as previously described for oca and mashua.

\section{Morphological properties}

\section{Scanning electron micrographs}

Morphological characterization of the isolated starches was carried out via scanning electron microscopy (SEM) using a modular high-vacuum coating system (Model MED 020, Bal-Tech) and an FEI Quanta 600 FEG model microscope. Samples were prepared and fixed in stubs on double-sided carbon tape and coated with platinum for plating in modular equipment at a pressure of $5.00 \mathrm{kV}$.

The distribution of starch granules in freeze-dried tubers was also observed, which were fractured and fixed as described above.

\section{Physicochemical properties}

\section{Chemical composition}

The starches and tubers were analyzed for moisture, lipid, protein and ash contents according to the methods described in the Association of Official Analytical Chemistry (1995). Total starch, analyzed by the method described by Areas and Lajolo (1981), and total carbohydrates were estimated by difference. The dietary fiber (DF) content was determined using the enzymaticgravimetric method (Prosky et al., 1992). Total sugars were measured with the phenol-sulfuric reaction (Dubois et al., 1956).

\section{Amylose content}

The starch amylose content was determined according to the method described by Morrison and Laignelet (1983), with some modifications. A volume of $5.0 \mathrm{~mL}$ of dimethyldisulfide and urea (UDMSO) at $6 \mathrm{M}, 9: 1$ was added to $40 \mathrm{mg}$ of isolated starch sample; the suspension was vigorously shaken and incubated in a boiling water bath for $30 \mathrm{~min}$, then placed on a stove at $100{ }^{\circ} \mathrm{C}$ for $90 \mathrm{~min}$. A $0.5 \mathrm{~mL}$ aliquot of this solution was diluted to $50 \mathrm{~mL}$ with distilled water and $1.0 \mathrm{~mL}$ I2-KI ( $2 \mathrm{mg} \mathrm{I}_{2}, 20 \mathrm{mg} \mathrm{KI} / \mathrm{mL}$ ). Finally, the absorbance at 635 $\mathrm{nm}$ was measured with a UV-Vis B582 spectrophotometer. The amylose content was determined with a standard curve, using stock amylose (from potato starch, SigmaAldrich Co. St. Louis, USA, A0512) and amylopectin (from potato starch, Sigma-Aldrich Co. St. Louis, USA, A8515) solutions.

\section{Swelling power (SP), water absorption capacity (WAC) and solubility}

The oca, olluco and mashua starch granules' swelling power, water absorption capacity and solubility were determined following the method proposed by Leach, McCowen, and Schoch (1959). Aqueous suspensions of $2 \% \operatorname{starch}(\mathrm{w} / \mathrm{v})$ were heated at constant temperatures (40, $50,60,70,80$ and $90^{\circ} \mathrm{C}$ ) in a water bath and shaken for 30 min. Each suspension was then cooled and centrifuged at $3,000 \mathrm{x}$ g for $15 \mathrm{~min}$; the residue was then weighed and the supernatant was dried at $105^{\circ} \mathrm{C}$ for $24 \mathrm{~h}$. The data obtained were used to calculate the water absorption capacity, swelling power and solubility of the starch granules. Water absorption capacity was expressed as the weight of the gel formed by each sample, divided by the treated sample weight. Percentage solubility and swelling power were calculated as in previous work (Torre-Gutierrez, ChelGuerrero, Betancur-Ancona, 2008) using the following formulas:

$\%$ Solubility $=$ dry weight at $120^{\circ} \mathrm{C} \mathrm{x} 400 /$ sample weight

Swelling Power $=$ weight of swollen granules $\mathrm{x} 100 /$ sample weight $\mathrm{x}(100-\%$ solubility $)$

\section{Starch gel clarity}

The clarity of the starch gels from oca, olluco and mashua were measured according to the method of Perera and Hoover (1999), by means of a $1 \%$ aqueous suspension placed in a water bath at a constant temperature $\left(90^{\circ} \mathrm{C}\right)$ with continuous shaking for $1 \mathrm{~h}$. The paste was cooled at ambient temperature and stored at $4{ }^{\circ} \mathrm{C}$ for 5 days. The starch gel clarity at $640 \mathrm{~nm}$ was measured every $24 \mathrm{~h}$ with a spectrophotometer (Micronal B582).

\section{Stability to freezing and refrigeration}

The conditions used to determine stability to 
freezing and refrigeration were adapted from Eliasson and Ryang (1992). A 5\% starch suspension was heated to $95^{\circ} \mathrm{C}$ for $15 \mathrm{~min}$; it was then cooled to $50^{\circ} \mathrm{C}$ and kept at this temperature for $15 \mathrm{~min}$. Aliquots of $10 \mathrm{~mL}$ were placed in centrifuge tubes and conditioned at three temperatures: room temperature, $4^{\circ} \mathrm{C}$ and $-18^{\circ} \mathrm{C}$, for 5 days. Every $24 \mathrm{~h}$, the samples were centrifuged at $8,000 \mathrm{x}$ g for $10 \mathrm{~min}$ and subsequently the percentage of water expelled during storage was measured to calculate syneresis.

\section{Thermal properties}

\section{Starch paste properties}

The properties of each starch paste were determined using a Rapid Visco Analyzer (RVA, Newport Scientific, United States). The starch samples (3 g dry basis) were suspended in $25 \mathrm{~mL}$ of distilled water (dry basis), equilibrated at $50{ }^{\circ} \mathrm{C}$ for $1 \mathrm{~min}$, heated at a rate of $5{ }^{\circ} \mathrm{C} / \mathrm{min}$ to $95^{\circ} \mathrm{C}$ and maintained at that temperature for $9 \mathrm{~min}$. The samples were then cooled to $50^{\circ} \mathrm{C}$ at a rate of $5{ }^{\circ} \mathrm{C} / \mathrm{min}$. The samples were stirred at $960 \mathrm{rpm}$ for $10 \mathrm{sec}$ to disperse the starch, after which time the stir drive motor was switched to $160 \mathrm{rpm}$ for the remainder of the test.

\section{Differential scanning calorimetry (DSC)}

A differential scanning calorimeter (DSC; Model 822e, Mettler Toledo, Simple Robot, TSO 801R0, operated with EXSTAR6000 software) was used to determine the starch gelatinization temperature. Seventy percent distilled water was added to $3.0 \mathrm{mg}$ of starch sample (dry basis) to form a suspension. The aluminum capsule (The PerkinElmer Corporation Norwalk, Connecticut USA) was hermetically sealed and balanced at ambient temperature for $1 \mathrm{~h}$ before heating. The system was calibrated with metallic indium and an empty aluminum capsule as reference. The samples were analyzed from 10 to $120^{\circ} \mathrm{C}$ at a heating rate of $10^{\circ} \mathrm{C} / \mathrm{min}$. The starch samples' thermal transitions were defined as $\mathrm{T}_{\mathrm{o}}$ (onset temperature), $\mathrm{T}_{\mathrm{p}}$ (peak temperature), $\mathrm{T}_{\mathrm{c}}$ (conclusion temperature) and $\Delta \mathrm{H}_{\mathrm{gel}}$, related to the enthalpy of gelatinization. The enthalpies were automatically calculated from the starch samples on a dry-mass basis.

\section{Textural properties of the starch gels}

The gels' textural properties were determined according to their texture analysis profile (TAP) using aTA/ XT2 equipment (Stable Microsystems, Surrey, England). A starch suspension of $6 \%$ was heated to $95^{\circ} \mathrm{C}$ for $15 \mathrm{~min}$, then cooled to $50{ }^{\circ} \mathrm{C}$ and kept at this temperature for 15 min. Forty milliliter portions of the paste were transferred to $50 \mathrm{~mL}$ beaker flasks and cooled at ambient temperature, then stored at $4{ }^{\circ} \mathrm{C}$ for $24 \mathrm{~h}$. The gels formed in the flasks were used directly in the texture analysis, and each gel was penetrated $10 \mathrm{~mm}$ by a $\mathrm{P} / 25$-diameter cylindrical probe. Two strength-time curves were obtained with a $1.0 \mathrm{~mm} / \mathrm{s}$ speed during the penetration cycles. The texture profile curves were used to calculate fracturability, hardness, cohesiveness, adhesiveness, springiness, gumminess and chewiness. The TPA analyses were conducted in triplicate.

\section{Statistical analysis}

The statistical treatment was performed by analysis of variance (ANOVA), followed by Tukey's test to compare the means at $(p<0.05)$, employing the software Statistica 7.0 (StatSoft Inc., Tulsa, OK, USA).

\section{RESULTS AND DISCUSSION}

\section{Morphological properties}

SEM allowed us to detail the morphological characteristics of isolated starch granules as well as of freeze-dried tuber samples. Figure 1 shows that oca starch granules (Figure 1A-A4) have a morphology that is primarily cylindrical, ellipsoid, and oval, with lengths between 7.99 and $54.30 \mu \mathrm{m}$ and diameters of 6.99 to $24.41 \mu \mathrm{m}$. Olluco starch granules (Figure 1B-B4) showed asymmetric, irregularly shaped granules with primarily ellipsoid, oval, conical and prismatic shapes, with a granule size distribution of 6.45 to $32.64 \mu \mathrm{m}$ in length and 5.68 to $23.18 \mu \mathrm{m}$ in diameter. Mashua starch granules (Figure 1C-C4) were smaller than those of the other tubers; they exhibited oval, spherical, and truncated granules and sizes between 4.39 and $16.29 \mu \mathrm{m}$ in length and 4.07 and $13.09 \mu \mathrm{m}$ in diameter.

These variations in starch granule morphology are attributable to the biological origins of the plants. The morphology of starch granules depends on the biochemistry of the chloroplasts or amyloplasts, as well as plant physiology (Singh et al., 2003). Moreover, several factors can affect the granules' properties, including such environmental factors as temperature, storage and cultural practices, thereby influencing the physicochemical and thermal properties of starch granules (Kaur et al., 2009).

The morphological characteristics of oca starch granules found in this study were similar to those reported by Santacruz et al., (2002) and Hernández-Lauzardo et al., (2004). The starch granules present in tubers like potato (Glaring, Koch, Blennow, 2006) and Canna edulis (Santacruz et al., 2002) have shapes that are somewhat similar to those of the oca. The morphology of olluco 

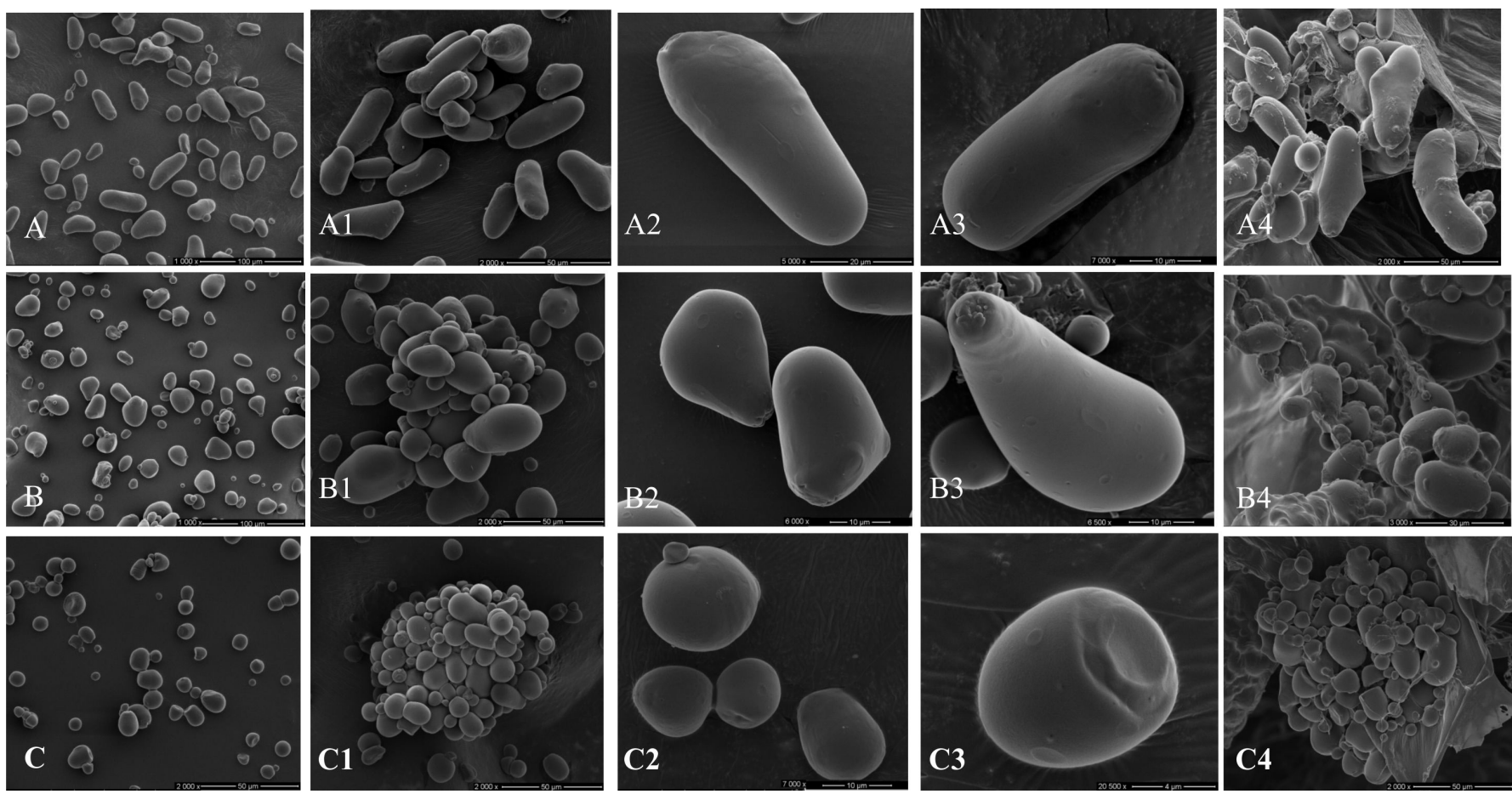

FIGURE 1 - SEM of isolated starches from oca (A-A3), olluco (B-B3) and mashua (C-C3). Images A4, B4 and C4 are from the respective freeze-dried samples.

starch granules was similar to that observed in the starches of some varieties of yam (Riley, Wheatley, Asemota, 2006). Moreover, mashua starch granules showed similar morphology to that of cassava (Manihot esculenta) starch (Peroni, Rocha, Franco, 2006; Hernández-Medina et al., 2008).

SEM also served as a control for the process of starch isolation, showing the integrity of the granules and the removal of all tuber cellular residues. Figure 1 (A4, B4, C4) displays the fracture of the tuber after lyophilization and shows that granules with similar sizes and the same morphology were observed in isolated starches. Furthermore, it is important to emphasize the ease and simplicity of the extraction process used in this work, which guaranteed the preservation of the starch granules and the removal of other compounds.

\section{Physicochemical properties}

\section{Chemical composition}

Table I shows the chemical composition of the whole samples and the isolated starches, expressed as the average of three replicates, and the standard deviation for each analysis. In terms of the chemical composition of the studied starch sources, mashua showed higher contents of protein, lipid, insoluble fiber and total sugars, and lower starch content when compared with oca and olluco. Oca presented lower protein, ash and soluble fiber contents than the other tubers.

In the proximate composition of the isolated starches, we identified traces of lipid in the olluco and mashua starches. It was also possible to identify levels of ash in all the isolated starches. However, the absence of other compounds indicated a good extraction and a pure starch. In this study, the three samples had a purity of $99 \%$.

According to Hoover (2001), the presence of low levels of lipid, protein and ash in starches from roots and tubers does not have pronounced effects on their functional properties. Because these compounds comprised less than $1 \%$ of the studied starches, the extraction process can be considered efficient, having resulted in a high level of purity according to previously established criteria (Rocha, Demiate, Franco, 2008; Torruco-Uco, Betancur-Ancona, 2007).

Hernández-Lauzardo et al. (2004) isolated starch from oca, obtaining $90.5 \%$ purity, with $0.34 \%$ protein and $0.52 \%$ lipid. The purity of our studied starches was similar to that of starches extracted from cassava (99.32\%) and corn (99.62\%) (Demiate, Oetterer, Wosiacki, 2001), and was higher than those reported for corn $(91.4 \%)$ and maca $(87.83 \%)$ by Hernandez-Lauzardo et al. (2004) and Rondán-Sanabria and Finardi-Filho (2009), respectively.

Similar amylose levels were found in the starches of the three samples: $26 \%$ for olluco, $27.6 \%$ for oca and 
TABLE I - Chemical composition of tuberous starch sources and their respective starches (dry basis and initial moisture; \%) ${ }^{\mathrm{a}}$

\begin{tabular}{lcccccc}
\hline Contents & \multicolumn{2}{c}{ Oca } & \multicolumn{2}{c}{ Olluco } & \multicolumn{2}{c}{ Mashua } \\
\cline { 2 - 7 } & Tuber & Starch & Tuber & Starch & Tuber & Starch \\
\hline Protein & $6.84 \pm 0.07$ & $\mathrm{NI}^{*}$ & $8.06 \pm 0.07^{*}$ & $\mathrm{NI}$ & $9.21 \pm 0.18$ & NI \\
Lipid & $0.72 \pm 0.03$ & $\mathrm{NI}$ & $0.65 \pm 0.01$ & $0.08 \pm 0.00$ & $0.92 \pm 0.04$ & $0.02 \pm 0.00$ \\
Soluble fiber & $0.29 \pm 0.02$ & $\mathrm{NI}$ & $6.49 \pm 0.41$ & 0.00 & $5.04 \pm 0.09$ & $\mathrm{NI}$ \\
Insoluble fiber & $6.85 \pm 0.34$ & $\mathrm{NI}$ & $7.22 \pm 0.21$ & $\mathrm{NI}$ & $10.55 \pm 0.03$ & $\mathrm{NI}$ \\
Total sugar & $23.28 \pm 2.02$ & $\mathrm{NI}$ & $5.26 \pm 0.35$ & $\mathrm{NI}$ & $27.70 \pm 1.18$ & $\mathrm{NI}$ \\
Starch & $56.82 \pm 1.01$ & $99.21 \pm 0.78$ & $64.96 \pm 1.97$ & $99.05 \pm 1.49$ & $41.35 \pm 1.60$ & $99.56 \pm 0.95$ \\
Amylose & $\mathrm{ND}$ & $27.60 \pm 0.41$ & $\mathrm{ND}$ & $26.49 \pm 0.86$ & $\mathrm{ND}$ & $27.44 \pm 0.43$ \\
Mineral residues & $4.48 \pm 0.03$ & $0.15 \pm 0.01$ & $5.40 \pm 0.20$ & $0.17 \pm 0.01$ & $5.10 \pm 0.09$ & $0.28 \pm 0.01$ \\
Moisture & $86.23 \pm 0.69$ & $10.93 \pm 1.06$ & $87.40 \pm 0.67$ & $10.97 \pm 0.09$ & $90.84 \pm 0.56$ & $8.44 \pm 0.31$ \\
\hline
\end{tabular}

${ }^{a}$ Data are presented as means \pm standard deviations of triplicate measurement; ${ }^{*} \mathrm{NI}$ : Not identified

$27.4 \%$ for mashua (Table I). These values are similar to those that Espín, Villacrés and Brito (2004) identified in olluco and mashua starches. Hernández-Lauzardo et al. (2004) and Espín, Villacrés and Brito (2004) reported amylose contents in oca starch of 33 and $29.0 \%$, respectively. Nevertheless, Santacruz et al. (2002) quantified lower amylose levels in oca starch (17.4 and $19.4 \%)$.

\section{Swelling power (SP), water absorption capacity (WAC) and solubility (S)}

The swelling power (SP), water absorption capacity (WAC) and solubility (S) of starches are directly correlated with temperature (Rondán-Sanabria, FinardiFilho, 2009). During the heating process of a starchwater suspension, the crystalline structure is disrupted due to the breakage of hydrogen bonds. The water molecules become linked by hydrogen bonding to the exposed hydroxyl groups of amylose and amylopectin, causing an increase in granule swelling and solubility (Hoover, 2001). In oca, olluco and mashua starches, these properties began to increase at temperatures of $50{ }^{\circ} \mathrm{C}$ (Figure 2).

Compared with oca and mashua, the SP of olluco starch was lower, indicating greater resistance to swelling, probably due to the presence of stronger associative forces maintaining the granule structure (Figure 2A). This corresponds to experimental results reported by other authors that related the low SP of yam and ginger starches, which began to increase at $60{ }^{\circ} \mathrm{C}$ (Peroni, Rocha, Franco, 2006; Leach, McCowen, Schoch, 1959).

Oca starch suspensions at temperatures of 60 to $80{ }^{\circ} \mathrm{C}$ had greater solubility than mashua and olluco starches (Figure 2B). At $90{ }^{\circ} \mathrm{C}$, neither the $\mathrm{S}$ nor SP for oca and mashua could be measured because there was no separation between the phases, a phenomenon that has also been observed in modified Peruvian carrot starch (Matsuguma et al., 2009).

Regarding WAC, the oca and mashua starches showed similar values at $60^{\circ} \mathrm{C}$. Between $70^{\circ} \mathrm{C}$ and $80^{\circ} \mathrm{C}$, mashua showed the highest WAC values. Finally, at $90^{\circ} \mathrm{C}$, mashua and oca reached a maximum value of $102.00 \mathrm{~g}$ water/g starch, followed by olluco, with $92.19 \mathrm{~g}$ water/g starch (Figure 2C). These values are high in comparison with those reported for taewa starch (35.00-40.56 g water/g starch; Singh, McCarthy and Singh, 2006) and maca starch (45.90 g water/g starch; Rondán-Sanabria, Finardi-Filho, 2009).

In starch granules, swelling power and solubility provide evidence of the magnitude of the interaction between starch chains within the amorphous and crystalline domains. The extent of this interaction is influenced by the amylose/amylopectin ratio and by the characteristics of amylose and amylopectin in terms of molecular weight/distribution, degree and length of branching, and conformation (Hoover, 2001).

These properties differ significantly according to the botanical source, morphology, organization and structure of the granules. In cereal starches, such as corn, the swelling is limited and occurs in two stages, suggesting the existence of two forces involved in the interactions between the polymer chains, which relax at different temperatures. However, in root and tuber starches, such as cassava and potatoes, the major swelling at low temperatures indicates weak and uniform interactions (Leach, McCowen, Schoch, 1959; Singh et al., 2003). 


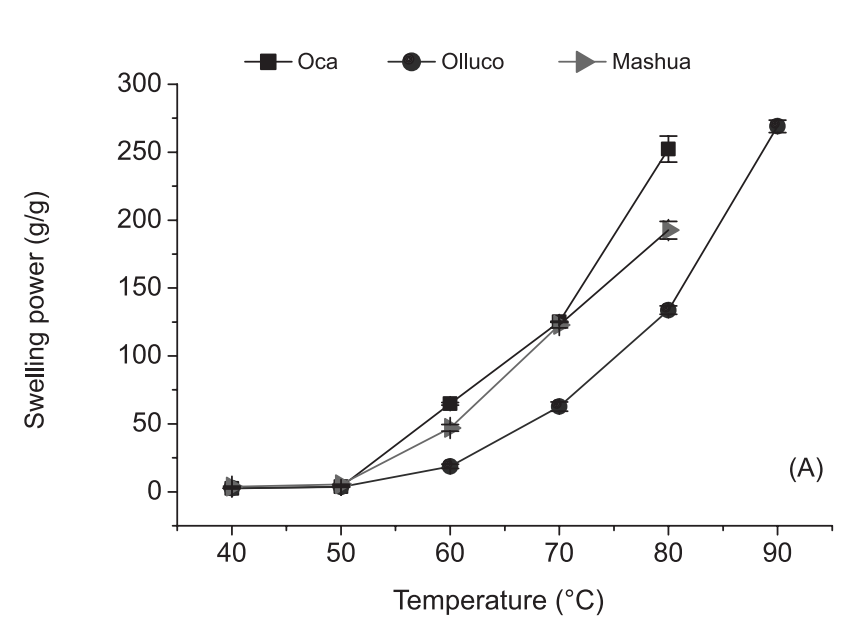

be attributed to a continued interaction between leached amylose and amylopectin chains and, to a lesser extent, to a short-range ordering of amylopectin side chains, which leads to the development of functional zones that reflect or scatter a significant amount of light (Perera, Hoover, 1999). The gelatinized suspensions of oca, olluco, and mashua starches showed progressive reductions in clarity during the storage period. Figure 3 shows the variations in clarity of suspensions of the three samples. Olluco (absorbance $0.11-0.16$ ) presented low clarity in relation to oca (absorbance 0.04-0.15) and mashua (absorbance $0.06-0.20)$, but showed better storage stability. This stability was similar to that previously reported for maca and Peruvian carrot starches (Rondán-Sanabria, Finardi-

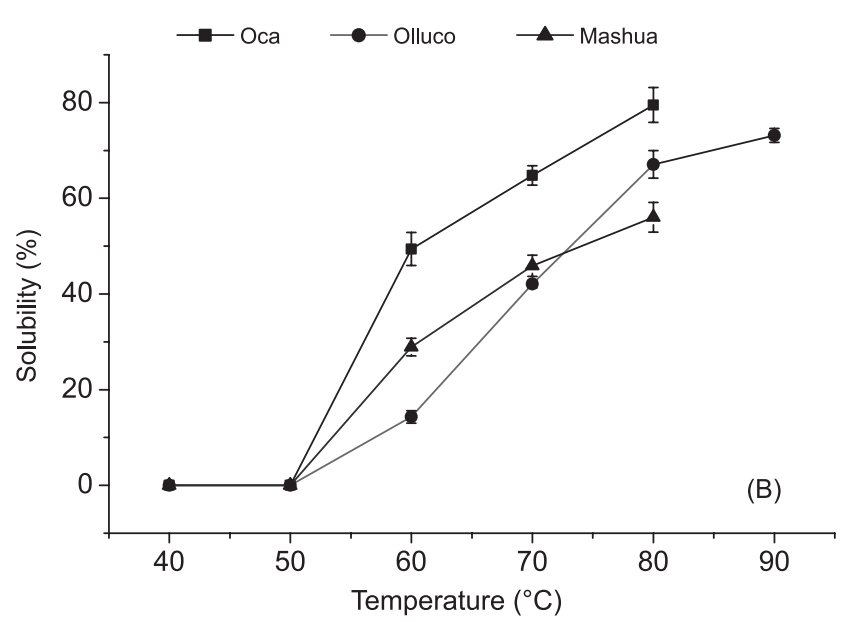

Filho, 2009). Oca showed high paste clarity compared with olluco and mashua, presenting a small, constant and progressive decrease in clarity until the fifth day of storage. In olluco and mashua starch solutions, a small increase in clarity was observed after the first day but clarity began to decline again after the second day. On day six, a further increase in turbidity for the three samples was observed, followed by a further decrease in the clarity of gelatinized mashua starch suspensions on day seven, indicating a greater turbidity of this starch in relation to olluco and oca.

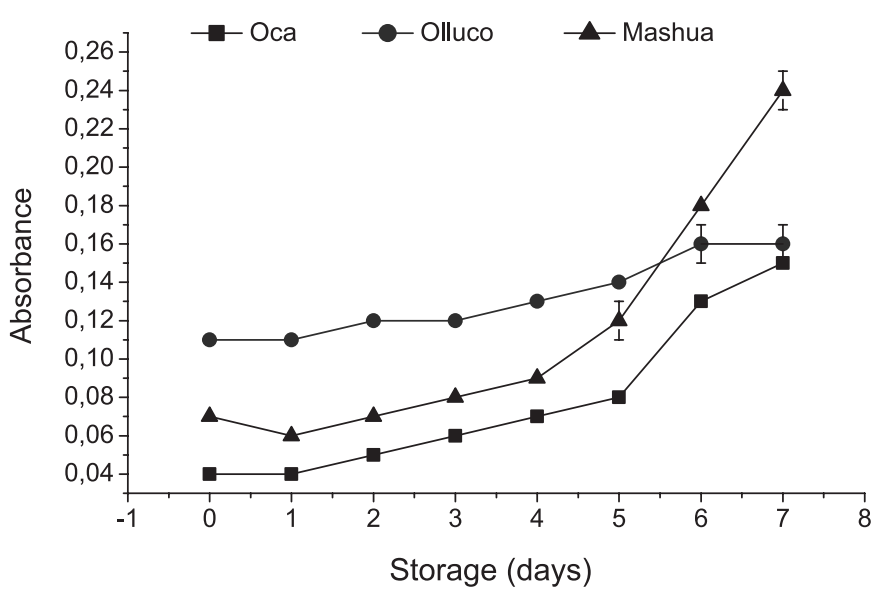

FIGURE 3 - Effect of storage on the paste opacity of oca, olluco and mashua starches.

The high initial clarity of native starch pastes could be attributed to their larger swelling factor, the repulsion between negatively charged phosphate groups covalently bound to amylopectin and the absence of granule fragments as observed by Perera and Hoover (1999). The clarity of these starches is lower than that of other starches, such as maca, which presented an initial turbidity corresponding to an absorbance of 0.51 and a gradual increase in turbidity over five days of storage at $4{ }^{\circ} \mathrm{C}$ (Rondán-Sanabria, Finardi-Filho, 2009). 


\section{Stability to freezing and refrigeration}

The retrogradation properties of starch granules are indirectly influenced by the structural arrangement of starch chains within the amorphous and crystalline regions. At the same time, this arrangement influences the degree of starch granule degradation during gelatinization, as well as the interactions between starch chains during storage (Perera, Hoover, 1999). The oca, olluco and mashua starch pastes presented high stability when stored at room temperature (not shown) and under refrigeration $\left(4^{\circ} \mathrm{C}\right)$, and did not present syneresis. Moreover, low stability and consequently high syneresis were observed when the three starches were stored at freezing temperatures $\left(-18{ }^{\circ} \mathrm{C}\right)$ (Figure 4). The water released from the viscous solutions of the three starches increased as the number of freezethaw cycles increased. This behavior was observed mainly in olluco, which showed less stability and consequently greater syneresis in relation to oca and mashua after the second thaw cycle, with $74.42 \%$ of water eliminated by the fifth day. After five days of storage, mashua starch presented low syneresis and, therefore, greater stability when frozen.

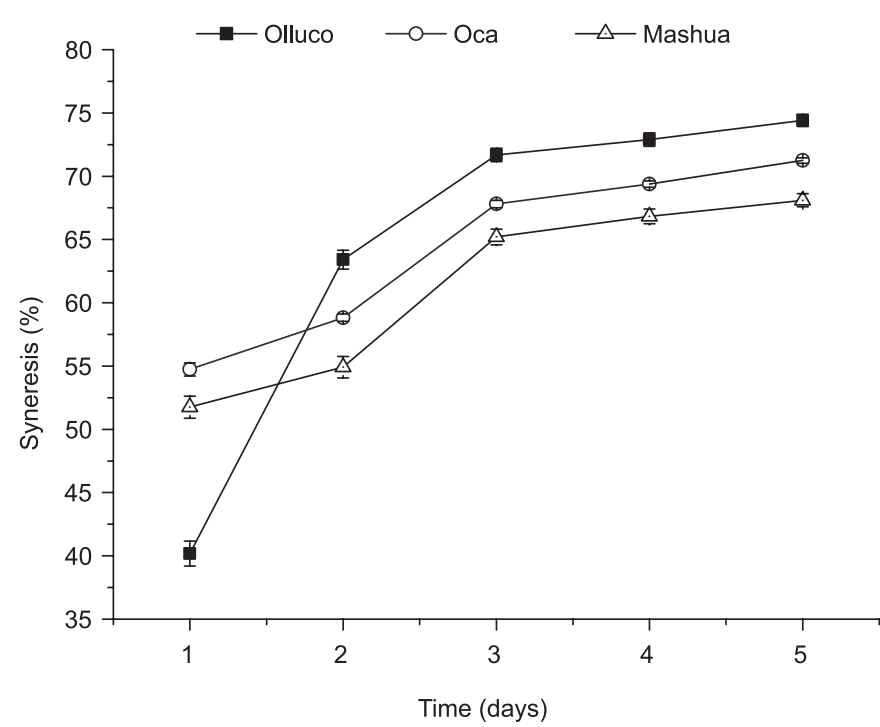

FIGURE 4 - Effect of storage on the paste stability of oca, olluco and mashua starches.

According to Miles et al. (1985) and Singh et al. (2006), in addition to low amylose content, low retrogradation in starch pastes is also possibly attributable to amylose aggregation and crystallization during the first hours of storage; amylopectin aggregation and crystallization occurs at later stages. Furthermore, Yamin et al. (1999) and Singh et al. (2003) list the length of the amylopectin chains, the degree of polymerization of the amylose and amylopectin, the degree of association between starch components, the presence of intermediate material and the size and shape of granules as other factors that play important roles in retrogradation during storage. On the other hand, when a starch paste is subjected to successive freeze-thaw cycles, the paste structure is affected because ice crystal growth and dissolution causes redistribution and dilution, which leads to changes in consistency (Hernádez-Medina et al., 2008).

Matsuguma et al. (2009) observed different levels of liberated water in native and modified starches of Peruvian carrot varieties, ranging from 3.70 to $87.80 \%$ for three freeze-thaw cycles applied to these samples. Native and modified banana starches subjected to four freeze-thaw cycles also showed low stability, with high syneresis of about $60 \%$ during the first and second thaw cycles (BelloPérez et al., 2002).

\section{Thermal properties}

\section{Differential scanning calorimetry}

The results for the gelatinization properties determined through DSC are summarized in Figure 5. $\mathrm{T}_{\mathrm{o}}$ was expressed at $50^{\circ} \mathrm{C}$, as expected, once the Swelling Power and Solubility values began to appear at the same temperature in the three samples. Olluco and mashua starches presented similar $\mathrm{T}_{\mathrm{o}}\left(52.81{ }^{\circ} \mathrm{C}\right.$ and $51.85^{\circ} \mathrm{C}$, respectively). Oca had the lowest $\mathrm{T}_{\mathrm{p}}\left(55.17^{\circ} \mathrm{C}\right)$ value compared with those for olluco $\left(58.93^{\circ} \mathrm{C}\right)$ and mashua $\left(56.92{ }^{\circ} \mathrm{C}\right)$ starches. $\mathrm{T}_{\mathrm{c}}$ was lowest for oca starch $\left(63.91{ }^{\circ} \mathrm{C}\right)$ and highest for olluco starch $\left(67.88^{\circ} \mathrm{C}\right)$. The thermal properties presented by the three starches were lower than those corresponding to makal starch $\left(\mathrm{T}_{\mathrm{o}}=72.6^{\circ} \mathrm{C}\right.$; $\mathrm{T}_{\mathrm{p}}=78.5^{\circ} \mathrm{C} ; \mathrm{T}_{\mathrm{c}}=84.2{ }^{\circ} \mathrm{C}$ and $\Delta \mathrm{Hgel}=15.0 \mathrm{~J} / \mathrm{g}$; TorrucoUco and Betancur-Ancona, 2007) and higher than those reported for maca starch $\left(\mathrm{T}_{\mathrm{o}}=45,7{ }^{\circ} \mathrm{C} ; \mathrm{T}_{\mathrm{p}}=47,7{ }^{\circ} \mathrm{C}\right.$; $\mathrm{T}_{c}=51.16^{\circ} \mathrm{C}$ and $\Delta \mathrm{Hgel}=6.22 \mathrm{~J} / \mathrm{g}$; Rondán-Sanabria, Finardi-Filho, 2009).

The enthalpies of gelatinization $(\Delta \mathrm{Hgel})$ for the three starches were similar $(9.66 \mathrm{~J} / \mathrm{g}$ for oca, $10.23 / \mathrm{g}$ for olluco and $9.78 \mathrm{~J} / \mathrm{g}$ for mashua). The $\Delta$ Hgel value gives an overall measure of crystallinity (quality and quantity) and is an indicator of the loss of molecular order within the granule, an effect that occurs with gelatinization. A smaller $\Delta$ Hgel suggests a lower degree of organization in, or a lower stability of, the crystals (Singh et al., 2006).

The oca starch study by Santacruz et al. (2002) showed similar results at $\mathrm{T}_{\mathrm{o}}\left(50.20^{\circ} \mathrm{C}\right), \mathrm{T}_{\mathrm{p}}\left(55.90^{\circ} \mathrm{C}\right)$ and $\mathrm{T}_{\mathrm{c}}\left(63.3^{\circ} \mathrm{C}\right)$, but with an $\Delta$ Hgel of $14.6 \mathrm{~J} / \mathrm{g}$. HernándezLauzardo et al. (2004) also observed a $\mathrm{T}_{\mathrm{p}}$ of $64.04^{\circ} \mathrm{C}$ with an $\Delta$ Hgel of $12.15 \mathrm{~J} / \mathrm{g}$ in oca starch. These variations in 
(A)

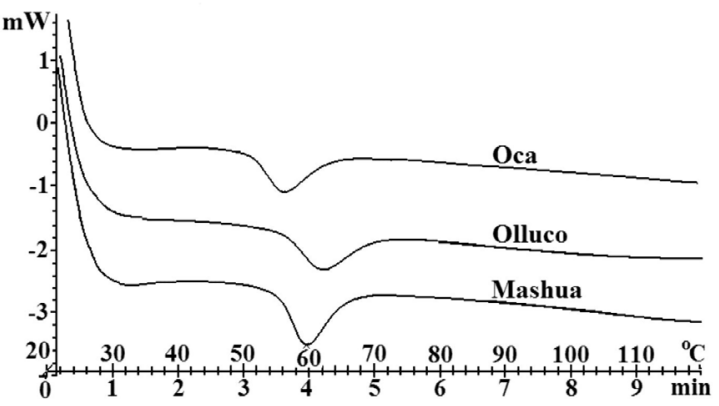

(B)

\begin{tabular}{lllll}
\hline Samples & $\mathbf{T}_{\mathbf{0}}\left({ }^{\circ} \mathbf{C}\right)$ & $\mathbf{T}_{\mathbf{p}}\left({ }^{\circ} \mathbf{C}\right)$ & $\mathbf{T}_{\mathbf{c}}\left({ }^{\circ} \mathbf{C}\right)$ & $\Delta \mathrm{H}_{\text {gel }}(\mathbf{J} / \mathbf{g})$ \\
\hline Oca & $50.26 \pm 0.30^{\mathrm{b}}$ & $55.17 \pm 0.03^{\mathrm{b}}$ & $63.91 \pm 1.43^{\mathrm{b}}$ & $9.66 \pm 0.68^{\mathrm{a}}$ \\
Olluco & $52.81 \pm 0.52^{\mathrm{a}}$ & $58.93 \pm 0.42^{\mathrm{a}}$ & $67.88 \pm 0.34^{\mathrm{a}}$ & $10.23 \pm 0.54^{\mathrm{a}}$ \\
Mashua & $51.85 \pm 0.41^{\mathrm{a}}$ & $56.92 \pm 0.10^{\mathrm{ab}}$ & $65.22 \pm 0.28^{\mathrm{b}}$ & $9.78 \pm 0.58^{\mathrm{a}}$
\end{tabular}

$\overline{\text { Mean values in the same column with different letters are significantly different }}$ $(p<0.05)$; To: initial temperature; Tp: temperature at the gelatinization peak;

Tc: final temperature; $\Delta \mathrm{H}$ : gelatinization enthalpy

FIGURE 5. (A) Differential scanning calorimetry thermograms of oca, olluco and mashua starches heated with $70 \%$ water at a rate of $10{ }^{\circ} \mathrm{C} / \mathrm{min}$; (B) Numeric data from the thermograms.

the thermal properties of oca starch could be attributed to various factors, such as variations in the amylose/ amylopectin ratio, amylopectin chain length, size and shape of the starch granules, moisture content, maturity state, and also some environmental conditions, such as pressure, mechanical damage, experimental conditions and variations in the methodology (Singh et al., 2006).

\section{Pasting properties}

Our results for the pasting properties of oca, olluco and mashua starches, as evaluated by RVA, are presented in Figure 6. They present as easy-to-cook starches, with oca presenting the shortest peak time $(2.78 \mathrm{~min})$. The paste temperature was lowest for oca starch $\left(63.56^{\circ} \mathrm{C}\right)$ and highest for olluco starch $\left(67.04^{\circ} \mathrm{C}\right)$, similar to the results obtained by DSC and presented above.

The low paste temperatures in oca and mashua starches, which also presented high swelling power, could indicate a lesser degree of association in the amorphous zones of the starch granules, and therefore less resistance to swelling. The oca starch paste had the lowest peak formation time when compared with olluco and mashua; after it reached maximum viscosity, its break was abrupt (7056.25 cP), showing less resistance $(756.33 \mathrm{cP}$ ) and greater tendency to retrogradation. Together this set of results shows that these starches have a weak stability against mechanical processes.

According to Higley et al., (2003), higher breakdown
(A)

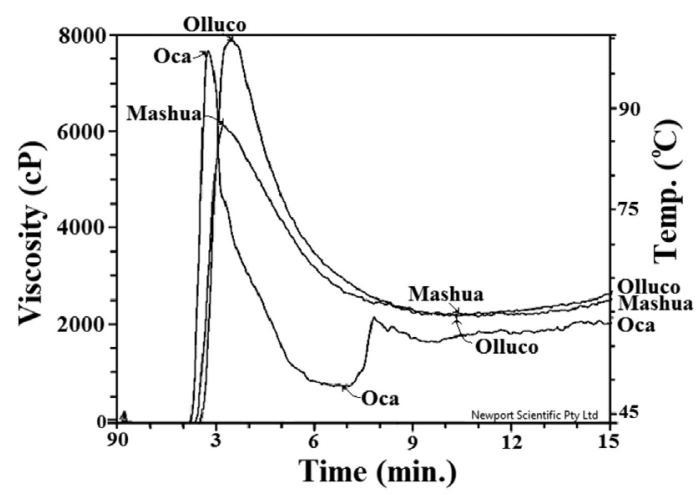

(B)

\begin{tabular}{lccc}
\hline \multirow{2}{*}{ Parameters } & \multicolumn{3}{c}{ Starch } \\
\cline { 2 - 4 } & Oca & Olluco & Mashua \\
\hline Peak viscosity (cP) & $7,715.25 \pm 41.98^{\mathrm{a}}$ & $7,782.75 \pm 10.66^{\mathrm{a}}$ & $6,202.00 \pm 140.71^{\mathrm{b}}$ \\
Strength (cP) & $756.33 \pm 59.35^{\mathrm{b}}$ & $2,186.25 \pm 42.73^{\mathrm{a}}$ & $2,203.75 \pm 21.48^{\mathrm{a}}$ \\
Breakdown (cP) & $7,056.25 \pm 95.47^{\mathrm{a}}$ & $5,585.25 \pm 29.68^{\mathrm{b}}$ & $3,899.00 \pm 73.78^{\mathrm{c}}$ \\
Final viscosity (cP) & $2,282.00 \pm 51.48^{\mathrm{c}}$ & $2,638.00 \pm 48.34^{\mathrm{a}}$ & $2,541.00 \pm 51.70^{\mathrm{b}}$ \\
Setback (cP) & $1,664.00 \pm 50.74^{\mathrm{a}}$ & $442.50 \pm 21.14^{\mathrm{b}}$ & $314.33 \pm 30.17^{\mathrm{c}}$ \\
Peak time (min) & $2.78 \pm 0.07^{\mathrm{c}}$ & $3.42 \pm 0.07^{\mathrm{a}}$ & $3.18 \pm 0.07^{\mathrm{b}}$ \\
Paste temperature $\left({ }^{\mathrm{o}} \mathrm{C}\right)$ & $63.56 \pm 0.58^{\mathrm{c}}$ & $67.04 \pm 0.10^{\mathrm{a}}$ & $65.20 \pm 0.37^{\mathrm{b}}$
\end{tabular}

Mean values in the same line with different letters are significantly different $(\mathrm{p}<0.05)$ "cP: centipoise,

FIGURE 6 - (A) Viscosity profiles from the RVA analysis of oca, olluco and mashua starch pastes; (B) Numeric parameters observed during viscoamylograms.

levels could be associated with a greater degree of collapse of swollen starch granules (low viscosity), corresponding to a greater release of solubilized starch with reassociation capability during the cooling phase. With oca starch paste, the high level of breakdown observed led to a reduced final viscosity $(2282.00 \mathrm{cP})$ compared to olluco and mashua. However, this loss of paste viscosity was not overcome by an increase in the viscosity resulting from retrogradation (setback), a behavior that was also observed in olluco and mashua starches. Olluco starch presented the highest final viscosity, showing greater stability to stirring and cooking. Miles et al. (1985) related this fact to the aggregation or association of amylose molecules. Mashua starch presented low setback, which can be related to the presence of amylose chains with high molecular weights (Peroni, Rocha, Franco, 2006).

\section{Texture}

The textural properties of oca, olluco and mashua paste, determined using a texture analyzer, are shown in Figure 7. As can be observed from their starch paste profiles (Figure 7A), those corresponding to the oca sample do not show fracturability. The oca and mashua 
starch pastes presented more hardness, gumminess and chewiness compared with olluco (Figure 7B). Paste firmness mainly originates from the process of retrogradation in starch pastes, which is associated with the syneresis and crystallization of amylopectin (Miles et al., 1985).

Oca and mashua starch pastes showed greater hardness (2.49 N and $2.15 \mathrm{~N}$, respectively) and fraturability (1.68 N and $1.19 \mathrm{~N}$, respectively), whereas olluco showed low values (1.29 $\mathrm{N}$ of hardness) without fracturability. These values are low when compared with maca starch gel (Rondán-Sanabria, Finardi-Filho, 2009), which presented elevated hardness $(4.13 \mathrm{~N})$ and fracturability $(2.23 \mathrm{~N})$. Variations in the textural properties of starch gels are mainly influenced by changes in the rheological characteristics of the amylose matrix, the volume fraction and rigidity of the gelatinized starch granules and the phosphorus content, as well as interactions between the dispersed and continuous phases of the gel (Singh et al., 2006).

(A)

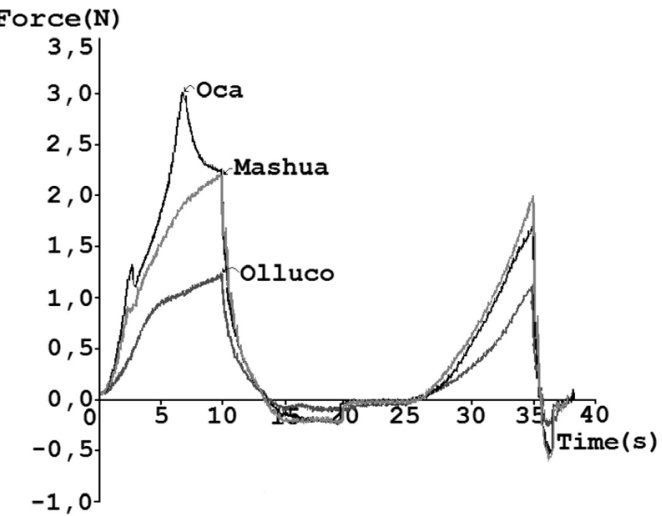

(B)

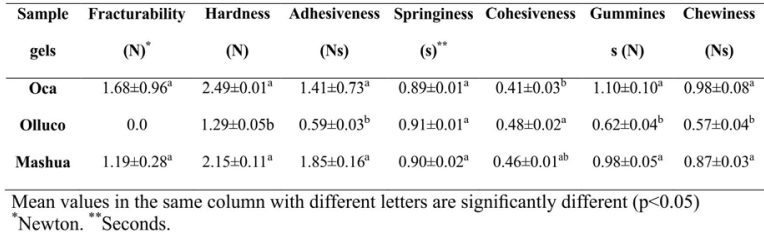

FIGURE 7 - (A) Texture profile analysis (TPA) curves of oca, olluco and mashua starch gels $(6 \% \mathrm{w} / \mathrm{w})$. (B) Measured TPA parameters.

Another factor that may influence the texture of starch pastes is swelling power. Starches with greater swelling power have a greater tendency to deformation, which affects the rigidity of the starch paste (Zhou et al., 1998). This fact was observed in oca and mashua starches, which showed greater swelling power than maca starch (Rondán-Sanabria, Finardi-Filho, 2009). The absence of fracturability in olluco starch paste could be related to its amylopectin content, which may influence the formation of more elastic gels. It is also important to consider the influence of other factors, such as starch gelling and gelatinization, strain rate and sample concentration, on gel formation.

\section{CONCLUSION}

The physicochemical and functional properties of starches from three unconventional Andean tuberous plants suggest that these starches can be used in food systems and other industrial applications, in products that require easy cooking, hot high viscosity, stability under refrigeration, and do not need to be frozen. Starch granule size could influence digestion; in this sense, mashua, with its comparatively smaller granules, could be a highly digestible starch. The absence of protein in the isolated starches indicates the utility of these starches for preparing syrups with high glucose content. The starches cook easily, have a high degree of swelling and solubility, high viscosity, low stability to stirring and cooking or mechanical action and a low tendency towards retrogradation. These starches showed high clarity, but with high syneresis when subjected to freeze-thaw cycles.

\section{ACKNOWLEDGEMENTS}

The authors would like to thank CNPq and CAPES for their financial support.

\section{REFERENCES}

AREAS, J.A.G.; LAJOLO, F.M. Starch transformation during banana ripening: I-the phosforilase behavior in Musa acuminate. J. Food Biochem., v.5, p.19-37, 1981.

UNITED STATES OF AMERICA. Association of Official Analytical Chemistry. Official methods of analysis of AOAC International. 16.ed. Arlington: AOAC International, 1995. $1025 \mathrm{p}$.

BARRERA, V.H.; ESPINOSA, P.; TAPIA, C.G.; MONTEROS, A.R.; VALVERDE, F. Caracterización de las raíces y los tubérculos andinos en la Ecoregión Andina del Ecuador. In: BARRERA, V.H.; TAPIA, C.G.; MONTEROS, A.R. (Eds.). Raíces y tubérculos andinos: alternativas para la conservación y uso sostenible en el Ecuador. Quito: Instituto Nacional Autónomo de Investigaciones Agropecuarias, 2004. cap.1, p.3-30. 
BELLO-PEREZ, L.A.; CONTRERAS-RAMOS, S.M.; ROMERO-MANILLA, R.; SOLORZA-FEIRA, J.; JIMENEZ-APARICIO, A. Propiedades químicas y funcionales del almidón modificado de plátano Musa paradisiaca L. (Var. Macho). Agrociencia, v.36, p.169-180, 2002.

BRASIL. Agencia Nacional de Vigilância Sanitária. Legislação. Visa Legis. Resolução RDC n.217, de julho de 2005. Extensão do uso do aditivo dióxido de enxofre e seus sais de cálcio, sódio e potássio. Available at: $<$ http://www4.anvisa. gov.br/base/visadoc/CP/CP[9938-1-0].PDF>. Access on: 28 Dec. 2010.

DEMiATE, I.M.; OETTERER, M.; WOSIACKI, G. Characterization of chesnut (Castanea sativa, Mill) starch for industrial utilization. Braz. Arch. Biol. Technol., v.44, p.69-78, 2001.

DUBOIS, M.; GILES, K.A.; HAMILTON, J.K.; REBERS, P.A.; SMITH, F. Colorimetric method for determination of sugars and related substances. Anal. Chem., v.28, p.350-356, 1956.

ELIASSON, A.C.; RYANG, H.K. Changes in rheological properties of hydroxipropyl potato starch paste during freeze-thaw treatments. J. Texture Stud., v.23, p.279-296, 1992.

ESPÍN, S.; VILLACRÉS, E.; BRITO, B. Caracterización físicoquímica, nutricional y funcional de raíces y tubérculos andinos. In: BARRERA, V.H.; TAPIA, C.G.; MONTEROS, A.R. (Eds.). Raíces y tubérculos andinos: alternativas para la conservación y uso sostenible en el Ecuador. Quito: Instituto Nacional Autónomo de Investigaciones Agropecuarias, 2004. cap.4, p.91-116.

GLARING, M.A.; KOCH, C.B.; BLENNOW, A. Genotypespecific spatial distribution of starch molecules in the starch granule: a combined CLSM and SEM approach. Biomacromolecules, v.7, p.2310-2320, 2006.

GODBILlOT, L.; DOLE, L.; JOLY, C., ROGE, B.; MATHLOUTHI, M. Analysis of water binding in starch plasticized films. Food Chem., v.96, p.380-386, 2006.

GROSS, R.; KOCH, F.; MALGA, I.; MIRANDA, A.F.; SCHOENEBERGER, H.; TRUGO, L.D. Chemical composition and protein quality of some local Andean food sources. Food Chem., v.34, p.25-34, 1989.
HERMANSSON, A.M.; SVEGMARK, K. Developments in the understanding of starch functionality. Trends Food Sci. Tech., v.7, p.345-353, 1996.

HER NÁN DEZ - L A UZ A R D O, A. N .; MÉNDEZ MONTEALVO, M.G.; VELÁZQUEZ DEL VALLE, M.G.; SOLORZA-FERIA, J.; BELLO-PÉREZ, L.A. Isolation and partial characterization of Mexican Oxalis tuberosa starch. Starch/Stärke, v.56, p.357-363, 2004.

HERNÁNDEZ-MEDINA, M.; TORRUCO-UCO, J.G.; CHEL-GUERRERO, L.; BETANCUR-ANCONA, D. Caracterización físicoquimica de almidones de tubérculos cultivados en Yucatán, México. Cienc. Tecnol. Aliment., v.28, p.718-726, 2008.

HIGLEY, J.S.; LOVE, S.L.; PRICE, W.J.; NELSON, J.E.; HUBER, K.C. The Rapid Visco Analyzer (RVA) as a tool for differentiating potato cultivars on the basis of flour pasting properties. Am. J. Potato Res., v.80, p.195-206, 2003.

HOOVER, R. Composition, molecular structure, and physicochemical properties of tuber and root starches: a review. Carbohydr. Polym., v.45, p.253-267, 2001.

KAUR, A.; SINGH, N.; EZEKIEL, R.; SODHI, N.S. Properties of starches separated from potatoes stored under different conditions. Food Chem., v.114, p.1396-1404, 2009.

LEACH, H.W.; McCOWEN, L.D.; SCHOCH, T.J. Structure of starch granule I. Swelling and solubility patterns of various starches. Cereal Chem., v.36, p.534-544, 1959.

MATSUGUMA, L.S.; LACERDA, L.G.; SCHNITZLER, E.; CARVALHO FILHO, M.A.S.; FRANCO, C.M.L.; DEMIATE, I.M. Characterization of native and oxidized starches of two varieties of peruvian carrot (Arracacia xanthorrhiza, B.) from two production areas of Paraná State, Brazil. Braz. Arch. Biol. Technol., v.52, p.701-713, 2009.

MILES, M.J.; MORRIS, V.J.; ORFORD, P.D.; RING, S.G. The roles of amylose and amylopectin in the gelation and retrogradation of sarch. Carbohydr. Res., v.135, p.271-281, 1985.

MORRISON, W.R.; LAIGNELET, B. An improved colorimetric procedure for determining apparent and total amylose in cereal and other starches. J. Cereal Sci., v.1, p.9-20, 1983. 
UNITED STATES OF AMERICA. National Research Council. Lost Crop of the Incas. Little-know plants of the Andes with promise for worldwide cultivation. Washington: National Academy Press, 1989. p.47-55.

PERERA, C.; HOOVER, R. Influence of hydroxypropylation on retrogradation properties of native, defatted and heatmoisture treated potato starches. Food Chem., v.64, p.361$375,1999$.

PERONI, F.H.G.; ROCHA, T.S.; FRANCO, C.M.L. Some structural and physicochemical characteristics of tuber and root starches. Food Sci. Technology. Int., v.12, p.505-513, 2006.

PROSKY, L.; ASP, N.C.; SCHWEIZER, T.F.; DEVRIES, J.W.; FUERDA, I. Determination on insoluble and soluble dietary fiber in foods and products: collaborative study. J. Assoc. Off. Anal. Chem., v.75, p.360-367, 1992.

RILEY, C.K.; WHEATLEY, A.O.; ASEMOTA, H.N. Full length research paper: isolation and characterization of starches from eight Dioscorea alata cultivars grown in Jamaica. Afr. J. Biotechnol., v.5, p.1528-1536, 2006.

ROCHA, S.T.; DEMIATE, M.I.; FRANCO, L.C.M. Características estruturais e físico-químicas de amidos de mandioquinha-salsa (Arracacia xanthorrhiza). Ciênc. Tecnol. Aliment., v.28, p.620-628, 2008.

RONDÁN-SANABRIA, G.G.; FINARDI-FILHO, F. Physiscalchemical and functional properties of maca root starch (Lepidium meyenii Walpers). Food Chem., v.114, p.492498, 2009.

SANTACRUZ, S.; KOCH, K.; SVENSSON, E.; RUALES, J.; ELIASSON, A.C. Three underutilised sources of starch from the Andean region in Ecuador Part I. Physico-chemical characterisation. Carbohydr. Polym., v.49, p.63-70, 2002.
SINGH, J.; MCCARTHY, O.J.; SINGH, H. Physico-chemical and morphological characteristics of New Zealand Taewa (Maori potato) starches. Carbohydr. Polym., v.64, p.569$581,2006$.

SING, N.; SINGH, J.; KAUR, L.; SODHI, N.S.; GILL, B.S. Review: morphological, thermal and rheological properties of starches from different botanical sources. Food Chem., v.81, p.219-231, 2003

SINGH, N.; KAUR, L.; SANDHU, K.S.; KAUR, J.; NISHINARI, K. Relationships between physicochemical, morphological, thermal, rheological properties of rice starches. Food Hydrocolloids, v.20, p.532-542, 2006.

TESTER, R.F.; KARKALAS, J.; QI, X. Review: starch composition, fine structure and architecture. J. Cereal Sci., v.39, p.151-165, 2004.

TORRE-GUTIERREZ, L.; CHEL-GUERRERO, A.; BETANCUR-ANCONA, D. Functional properties of square banana (Musa balbisiana) starch. Food Chem., v.106, p.1138-1144, 2008.

TORRUCO-UCO, J.; BETANCUR-ANCONA, D. Physicochemical and functional properties of makal (Xanthosoma yucatanensis) starch. Food Chem., v.101, p.1319-1326, 2007.

YAMIN, F.F.; LEE, M.; POLLAK, L.M.; WHITE, P.J. Thermal properties of starch in corn variants isolated after chemical mutagenesis of inbred line B73. Cereal Chem., v.76, p.175$181,1999$.

ZHOU, M.; ROBARDS, K.; GLENNIE-HOLMES, M.; HELLIWELL, S. Structure and pasting properties of oat starch. Cereal Chem., v.75, p.273-281, 1998.

Received for publication on $27^{\text {th }}$ April 2012 Accepted for publication on $30^{\text {th }}$ January 2013 